\title{
A Preliminary Study on the Javanese Folklore as a Disaster Mitigation Strategy
}

\author{
Fitri Nur Lita Indriana $^{1 *}$, Yogi Aji Pangestu ${ }^{1}$, Bintang Amanda ${ }^{1}$, Anita Damar Ranti ${ }^{1}$, and \\ Rabith Jihan Amaruli ${ }^{1}$
}

${ }^{1}$ Department of History, Faculty of Humanities, Diponegoro University, Semarang, Indonesia

\begin{abstract}
Generally, people assume that Javanese Folklor is commonly dominated by myths. In fact, some of Javanese Folklor contains numerous knowledge of local wisdom on disaster mitigation. Nowadays, disaster mitigation is proceeded only based on scientific knowledge and technology. Meanwhile, there are some cultural knowledges on disaster mitigation which are mostly forgotten and scarcely applied. People will assume that the knowledge is just a myth and should be ignored. Therefore, this study reveals the Javanese traditional knowledge for disaster mitigation through identification of folklores. Using anthropological history approach, this study reveals hidden values in every occasion from Javanese folklores such as the story of Timun Mas, Rawa Pening, and Nyi Roro Kidul. Timun Mas provides an information regarding to reclamation of ex-mining land for mud volcano disaster, Rawa Pening gives a lesson on how to keep lake area clean to prevent from flooding, while Nyi Roro kidul teaches us to developing mangrove forest from tsunami. Thus, this study offers values about traditional knowledge on disaster mitigation that can be contextualized in the present-day effort as survival strategy in a disaster.
\end{abstract}

\section{Introduction}

Geographically, the territory of Indonesia is situated at the meeting point of 3 continental plates of Eurasian Plate, Indo-Australian Plate, and Pacific Plate, making it located in the "Ring of Fire", which is an area where natural disasters such as volcano eruption, earthquake, tsunami, flood, and landslide often occur [1]. Based on the facts revealed, natural disasters usually occur in Indonesia [2]. At any place and time, disasters will indeed cause negative impacts. In the last decade, Indonesia has had several natural disasters which are classified into catastrophes, such as the tsunami in Aceh in 2004, the earthquake in the south of Java in 2006, Mount Merope eruption in 2010 at the same time as the tsunami in Mentawai, earthquake in Lombok, and earthquake followed by a tsunami in Paul, Sigil and Dongola. When a disaster occurs, many individuals are exposed to it, often causing a massive number of death tolls. In addition, the high intensity of disaster may cause loss, both economically and in other physical sectors, making post-disaster rehabilitation and construction require much cost [3]. The high rate of loss inflicted by disaster is caused by

*Corresponding author: fitrinurlitaindriana@students.undip.ac.id 
factors such as the fact that many people in Indonesia live in disaster-prone areas, lack of knowledge of disaster mitigation, and proneness of the quality of infrastructure, both public and non-public [3]. Unfortunately, disaster mitigation is currently only reflecting on science and technology. Disaster mitigation which uses a cultural approach lacks attention [4]. The conception of local wisdom is losing its meaning because of developing human civilization. Consequently, the relationship between nature-tradition and humans is disconnected [4], metaphysics and phenomenology become less known, in which the modern society is also getting away from nature [4].

Folklore is derived from English "folk" and "lore". Folk means a group of people with physical, cultural and social characters distinguishing them from other cultures in general. At the same time, lore is defined as culture passed down from generation to generation from different groups of people, either of oral form, a mnemonic device, or gesture [5]. The Indonesian people consist of a pluralistic society. Thus Indonesia is rich in folklores that are passed down from previous generations. One of the folklores discussed is Javanese folklore. Javanese folklore is one of Javanese culture, an expression related to hidden messages, with specific values, the local identity of Javanese society, and the source of information about Javanese culture [6]. Therefore, it is appropriate to learn the values of Javanese culture in folklore for them to be applied to disaster mitigation. The reason is that the hidden values of disaster knowledge of the Javanese people in folklore are obtained from the human mind realm in the process of improving life balance, which is a combination of organic, psychological and social systems, elaborated in the form of cognitive symbolization [7], in which the knowledge values are built on aesthetic rationality created from time to time [8].

Folklore consists of folktale, fairytale, legend, myth, or other matters clearly expressed in the proverb, saying, pantun, folk song and others [5]. One of the Javanese Folklores that may be used in disaster mitigation is a folktale. When the ancestors passed down folklore to the next generation, they chose folktale since it contained noble values, which may be taken as life guidance for the next generation, such as honesty, responsibility, mutual aid, discipline, religiosity, and others [9]. The values should be tracked and studied to be comprehended by the next generation in disaster mitigation. Some folktales of the Javanese society famous in Indonesia include Timun Mas, Rawa Pening, and Nyi Roro Kidul. In general, the folktales are only deemed myth, but in fact, the three can be traced for their correlation with natural disasters that had been traced in the past; thus, from the tracing will the knowledge values of disaster mitigation be obtained. Therefore, based on the explanation above, what is the role of Folktales Timun Mas, Rawa Pening, and Nyi Roro Kidul in the knowledge of disaster mitigation in the Javanese society?

\section{Research Methods}

This literature study was conducted in four stages: literature collection, literature verification, literature analysis, and literature display. Literature collection was conducted by searching for many kinds of literature relevant to folktale and disaster mitigation. The keywords were folktale, disaster mitigation, folklore, local wisdom, tsunami, flood, mud, myth, Timun Mas, Rawa Pening, Nyi Roro Kidul, and indigenous knowledge. The literature collected were 25 journals and five proceedings found in accredited national and international journal portals such as Science Direct, Cambridge Core, JSTOR, and Google Scholar. In addition, the author also used two books for reference, making reference used of a totally of 32 kinds of literature. Literature verification was used externally and internally by applying journal, proceeding and book criteria related to folktale and disaster mitigation. The data were then analyzed by referring to the processes of choice, simplification and interpretation associated with meanings [10] to find the ideas used in genuine 
strengthening. The results of the processes were followed with the data display process by arranging the writing into a harmonious formulation.

\section{Result and Discussion}

\subsection{Javanese Folklore on Disaster Mitigation}

Folktale as one of the oral traditions produced through lineage from generation to generation boasts rich values as life guidance, such as the values of morality towards humans, sacred morality towards God, and morality towards nature or the surrounding environment, as a reminder that nature is the source of life obtained from God Almighty [11]. The myth presented in folktale is the track record of the past event once experienced by the people of the particular area formed by cultural contact with nature, directly influencing the emergence of fairytales resulting from a previously existing event of which concept is called geo-mysticism [12]. Local wisdom plays a relatively important role in supporting society's effort to improve community resilience in the face of disaster [13]. It is intended that humans always keep nature balanced to prevent natural disasters and minimize the negative impacts resulting. Some disaster mitigation related Javanese folktales are Timun Mas, Rawa Pening, and Nyi Roro Kidul.

\subsubsection{Timun Mas}

Timun Mas is a Javanese folktale telling a story of a brave girl who tried her best to fight and escape from Buto Ijo, who attempted to feast on her [14]. It is necessary to know that the Indonesians have known the story of Timun Mas from ancient times as one of the folktales in the archipelago spreading widely in the society [15]. The story of Timun Mas started when Mbok Srini - usually called Mbok Rondo- desired a child. Like what the nickname means, Mbok Rondo lived alone, that her husband died without leaving any child. Day by day, Mbok Rondo always prayed to God for a child to accompany her spending her old age. One day there was a giant known as Buto Ijo came and gave her a cucumber seed. Buto Ijo said that one day when the cucumber seed had grown to be a giant-sized cucumber, he would come again to eat the cucumber [16]. Mbok Rondo finally planted the cucumber seed, and some weeks later, when the cucumber was split from within, it came out an adorable baby. The baby was named Timun Mas. In short, when Timun Mas had grown up, Buto Ijo came again to claim what Mbok Rondo had promised him of giving him, Timun Mas. However, Mbok Rondo did not have the heart if Timun Mas was to be a meal of Buto Ijo so that she ordered Timun Mas to escape and gave her some items given to her by a hermit as weapons to fight against Buto Ijo [14].

Facing Buto Ijo, Timun Mas prayed and made some attempts to fight him by throwing the items given by Mbok Rondo. The first step was throwing cucumber seeds, and the seeds magically proliferated, creeping and entangling Buto Ijo's body. Unfortunately, Buto Ijo was able to escape and again pursued Timun Mas. The second step was throwing a pack of needles, which transformed into bamboo trees standing up straight, high and pointed. The bamboo trees were able to make Buto Ijo's feet and legs bleed, but still, Buto Ijo could pass through the pointed bamboo trees. Seeing her unsuccessful attempts, Timun Mas then threw salt, which later had the forest transformed into the sea. Buto Ijo almost got drowned, but his gigantic body helped him survive the sea waves. Timun Mas was panicking and relentless, seeing all of her attempts unable to destroy Buto Ijo. There was only one pack remaining held by Timun Mas, and she prayed wholeheartedly for help to fight Buto Ijo. In the last pack was shrimp paste, which she immediately threw and immediately, the shrimp 
paste transformed into hot mud, which was able to suck anything therein. Finally, the violent hot mud could suck Buto Ijo's body, rendering him unable to resurface to pursue Timun Mas. The implementation of the folktale Timun Mas was that the giant was a symbol of disaster, while the packed items with magic power were the symbol of nature. The relationship between the giant and Timun Mas was interpreted that when humans respect nature, any disasters will be avoided or minimized [16].

The correlation of Timun Mas with disaster mitigation may be observed from the information that Timun Mas is a variant of the Story of Panji during Hindu-Buddhism Eras in the time of Jenggala Kingdom, where historical-literary records state that one of the causes of Jenggala Kingdom was flood [17]. Satyana's view revealed the uniform territorial topology in the Brantas Delta zone between Jenggala Kingdom and Majapahit Kingdom territories close to the area of Lapindo Mud phenomena written in Babad Pararaton, Serat Kenda, Folktale of Jenggala, and geological principle. Therefore, one of the factors regarding the hypothesis on mud disaster expected to have occurred during the time of the Jenggala Kingdom and Majapahit in the geological study was called mud volcano [18]. The soil of Brantas Delta is classified as unstable since underneath is seven ranges of continuously moving anticline, connecting the end of Kendeng Mountains to Madura Strait, which is supported by a source of an old manuscript, The Pararaton, where there is information that in 1296 Caka or 1374 AD there was a disaster of "Pagunungan Anyar". Thus the appearance of Timun Mas was inspired by the mud volcano disaster phenomena [17], with a narration that Buto Ijo died drowning, sucked by hot mud. The similarity in territorial topology in the Brantas Delta zone is also revealed by a Member of the Indonesian Association of Geologists (IAGI) of East Java, stating that the existing torrent of mud in Porong (Sidoarjo), Sedati, Mount Anyar Surabaya through Bangkalan is on a fault line [17]. The "mud volcano" phenomena were also recorded in the geologic map made by the Netherlands in 1938, where there was a record of 2 torrents of "mud volcano" in the area. Moreover, it is currently proven that the location of exploration and exploitation of PT. Lapindo, that is Brantas Block, is on the route of "active mud volcano" extending from Purwodadi-Cepu-Bojonegoro-Porong [18]. The mud volcano phenomenon in Sidoarjo is marked with the high temperature of the torrent close to $1000 \mathrm{c}$ on the surface close to the centre of the torrent [18]. The geological structure and layout that match the mud eruption occurring will be influenced by anticlinorium. The correlation refers to historical data that the torrent of mud volcano in East Java had also occurred for some periods in the history of Majapahit[17]. Therefore, a conclusion may be made that Geo-Cultural disaster is related to the culture of an area in geological phenomena.

\subsubsection{Rawa Pening}

Another disaster mitigation existing in folktale is the flood disaster mitigation of the Folktale of Rawa Pening. The folktale of Rawa Pening is derived from Kebondowo Village, Banyubiru District, Semarang Regency, Central Java Province [12]. In reality, Rawa Pening is a small lake or swamp. Rawa Pening tells a story that in the past, precisely on the valley between Mount Merbabu and Mount Telomoyo, there was a village named Ngasem [19]. In Ngasem Village, there was a couple, Ki Hajar and Nyai Selakanta. Their marriage had lasted for quite long, but it was as if God still had not willed to grant them a child. Therefore, Ki Hajar decided to pray to God in a cave for a child. Not long after, Nyai Selakanta gave birth to a boy. Oddly enough, however, the boy was in the shape of a talking dragon. The dragon was named Baru Klinthing. When Baru Klinthing grew up, he met Ki Hajar in the cave of his hermitage, and a command was given to Baru Klinthing to meditate in Tugur Hill. Sadly, in his meditation, Baru Klinthing was caught by the 
people of Pathok Village. His body was cut into pieces and cooked as food for a party. Miraculously, this turned Baru Klinting into a complete human.

Turning into a complete human, Baru Klinthing slowly felt hungry, and he then asked for food from the people of Pathok Village who were partying, eating his dragon body. However, unfortunately, none of them paid him any attention and did not give Baru Klinthing any food, even the least. In retaliation, Baru Klinthing stuck a coconut leaf stick into the ground and challenged the villagers to pull it out. However, no one was able to pull it out. Finally, with his supernatural power, Baru Klinting pulled the coconut leaf stick. From the hole where the coconut leaf stick was pulled out from flew water fast and nonstop until finally, the water submerged Pathok village. At a later date, the area was known as Lake Rawa Pening. Moreover, the correlation between Rawa Pening and local people was realized by making legendary folktales such as the story of Baru Klinthing [20]. Therefore, it is quite possible to associate the story of Rawa Pening to the flood once occurring in the area around the lake.

\subsubsection{Nyi Roro Kidul}

The importance of local wisdom regarding disaster increased rapidly with the Tsunami hitting the Indian Ocean [21]. When Tsunami hit the coastal areas of Southeast Asia in 2004, some societies with local knowledge of the Tsunami were able to survive, such as the story of the people of Simeulue Island [22]. Those who survived were those who applied the knowledge of tsunami disaster mitigation based on local wisdom. Tsunami disaster mitigation based on local wisdom is considered to play an essential role in minimizing the negative impacts caused by tsunami disasters [23]. The high intensity of waves in the Indian Ocean along the south coast of Java had the people on the coastal area aware and fearful, making them improve their vigilance by delivering offerings to the Queen of the South Coast, Nyi Roro Kidul. The folktale of Nyi Roro Kidul had existed from the Islamic Mataram Kingdom era and developed through words of mouth, reaching and being known by the current generation. The folktale of Nyi Roro Kidul is related to some south coastal areas of Java such as Pelabuhan Ratu, Pangandaran, Parangtritis, Parangkusumo, Karang Bolong, Ngliyep, Puger, Banyuwangi, and several other areas in the south of Java Island [23]. It is as if the myth of Nyi Roro Kidul as the ruler of the south sea of Java Island never fades away [24]. In general, Nyi Roro Kidul is a queen who controls the South Coast, where the people often ask pesugihan to Nyi Roro Kidul. Nyi Roro Kidul is visualized as a powerful woman who loves handsome men [25]. All paintings depicting the face of $N y i$ Roro Kidul always contain green elements on them, since according to the Javanese people's belief, Nyi Roro Kidul likes green very much [23]. Thus any tourists visiting the South Coast are suggested not to wear green clothes to get drowned, taken away by $N y i$ Roro Kidul. Nyi Roro Kidul is also often described wearing royal clothes of HinduBuddhism eras and a green scarf [26].

Another story of Nyi Roro Kidul is her relationship with Islamic Mataram. Based on a Javanese legend in the 16th C, Panembahan Senapati desired to establish an Islamic Mataram Sultanate intending to fight against Pajang Sultanate. Panembahan Senapati meditated in Parang Kusumo Beach, and in his meditation, a beautiful woman surrounded by supernatural power came. The Queen was fascinated by the handsome Panembahan Senapati and asked him to stop his meditation [25]. Nyi Roro Kidul was willing to fulfil Panembahan Senapati's request to help establish a new kingdom. In return for becoming the kingdom's guardian, the Queen asked him to take her as his wife, as the "Spiritual Consort" of the Islamic Mataram Kingdom from Panembahan Senapati through all of his descendants, Kings of Islamic Mataram Sultanate [23]. In the folktale, Nyi Roro Kidul was described as controlling the waves of the Indian Ocean, where the magical kingdom of $\mathrm{Nyi}$ 
Roro Kidul was located at the centre of the South Sea of Java. During the Tsunami disaster, many people believed that the big sea waves were deemed to be controlled by Nyi Roro Kidul [23]. Eko Yulianto, an expert of the Indonesian Institute of Sciences (LIPI), found that about 400 years ago, there was a big earthquake followed by Tsunami. A myth states that it was related to the establishment of the Islamic Mataram Sultanate [27]. In addition, Eko Yulianto also states that the story of and report on Tsunami occurring are written in the Old Javanese Manuscript, Babad Tanah Jawi.

\subsection{A Moral Value of Disaster Mitigation Strategy}

\subsubsection{Reclamation of Ex-Mining Land}

The story of Timun Mas contains moral values in mitigating the natural disaster of mud torrent. The event told in the plot of Timun Mas is the metaphor of an individual who desired to fight for human life depending on nature, as illustrated through the birth of Timun Mas from a cucumber seed, signifying that humans are very close to nature [14]. Timun Mas bears hidden meanings that humans struggle for survival by depending on nature. Based on the narration of Timun Mas, there is a correlation connecting culture and nature, which may be taken from the values of human belief that greed may bring disaster, just like what Buto Ijo did. Buto Ijo's character was described as an analogy of greedy human characteristics of eating produce excessively, while Timun Mas was a human who cared about nature. Humans should respect nature as something precious, but humans' greed and exploitation cause the existing damages [28]. The entangling cucumber vines, the feet piercing bamboo trees, the sea that caused anything to drown, and the mud which sucked Buto Ijo are the metaphors of antagonists trying to fight against the environment and destroy it [14]. The giant did not only constitute an antagonist, that he was aware of his necessity for survival by depending on nature, as shown with his act of giving Mbok Rondo cucumber seeds. However, he destroyed nature in fulfilment of his need for food. Therefore, humans should always keep nature preserved so as not to anger it because of their behaviour of exploiting and destroying nature.

The story of Timun Mas gives a hidden mandate that humans have high curiosity to investigate and search for understanding of the current natural events, incredibly natural disaster "mud volcano". Timun Mas's high curiosity saved her from Buto Ijo by trying to identify the use of some items given by Mbok Rondo as weapons. The correlation of high curiosity with natural disasters raises human's vigilance to prepare anything when a disaster occurs to mitigate the negative impacts it causes [15]. High curiosity is correlated, that if humans utilize nature, such as in drilling, they must perform reclamation to repair the environmental order condition. Thus the environmental ecosystem will remain balanced. The definition of reclamation is the activity to repair or organize the use of land harmed by mining activities so that the land will keep functioning and utilizable [16]. In reclamation intending to repair the land condition because of mining by placing a block of reclamation area in an orderly way so that mining activities can still be performed gradually under the allocated time, mining activities should be conducted through "backfilling" technique, that is filling immediately after mining process and re-vegetation, and further mining activities can be conducted gradually on the slope above it [29]. Therefore, humans are required to have extensive knowledge to know suitable drilling methods so as not to destroy the drilling area like that in Lapin do disaster that has not ended until now. Nature is the dynamics that must be protected and saved by humans, especially regarding the prevention of excessive exploitation of produce, as reflected in the folktale of Timun Mas.

In addition, facing difficulty, humans should never forget and pray to God. We can see in the story of Timun Mas that gratitude and pray should always be shown when humans 
are both in happy or sad situations [15]. Mbok Saini showed gratitude for having a child, and Timun Mas always prayed and had a strong belief in the face of Buto Ijo. Praying and remembering God will bring out the positive character in the face of difficulty. The positive character will affect one's motivation to support and show empathy to others [30].

\subsubsection{Keep Lake Area Clean}

Baru Klinthing is deemed as a dragon that guards Lake Rawa Pening. This makes the people around the Lake compliant, not to disappoint their ancestors and belief in the Rawa Pening area of the supernatural power. Thus the folktale of Rawa Pening made the people guard Lake Rawa Pening [12]. Directly, the amount of water in Lake Rawa Pening is influenced by the abundance of rainfall, groundwater appearing as a wellspring, and surface water, and the condition of territorial topography and human activities also indirectly contribute to influencing the amount of water [20].

From the 1970s, this Lake has often been flooded in the rainy season, particularly on the Tuntang Hilir watershed, because of sedimentation occurring continuously [20], making Lake Rawa Pening until now often flooded. The submersion of Pathok Village teaches flood disaster mitigation. The people are required to keep clean and preserve rivers, lakes, and water canals so that there will be no flood in case of heavy rainfall because of blocked water flow. The people are required not to pollute the environment, especially the lake environment. A flood is a disaster caused by human action. Thus, humans need to keep the environment balanced by not littering around so that water flow will not be blocked in the rainy season since generally, a flood occurs because of blocked water canal because of people littering around. Moreover, the primary sources of water pollution in Rawa Pening are nitrogen and phosphor derived from people's waste, livestock waste, agricultural waste, and fish feed waste [31]. Therefore, it needs people's awareness to keep the lake environment clean.

\subsubsection{Developing Mangrove Forest}

The concept of the people of the south coast of Java-related to the threat of giant waves, along with the myth of Nyi Roro Kidul, the ruler of the sea, who can control the sea waves, encourages the people to perform preventive measures to mitigate the impacts of the big waves. One of the measures is to Nyamplung and mangrove along the coast to withstand tsunami waves and as the primary boat making material [13]. With the discussion on reducing the harm of tsunami and also protection of the coastal area from other coastal ecological threats, we may conclude that it is necessary to make a coastal area protection zone by developing mangrove forest as a coastal forest. It is also necessary to know that mangrove forest plays a role in the stability of the coastal area. In addition, many also get more aware of the importance of mangrove forests as the protector of the coastal area from various natural disasters, especially tsunami [32]. Physically, mangrove forests growing in coastal areas can withstand the sea splashing, wind, storm, and tsunami waves [33]. The research in Japan shows that mangrove forests of $200 \mathrm{~m}$ with a density of 30 trees $/ 100 \mathrm{~m} 2$ and with a tree diameter of 15 centimetres $(\mathrm{cm})$ may reduce about $50 \%$ energy of tsunami waves [34].

Mangrove forest is the leading ecosystem in supporting the life of coastal areas since it has the productivity and complexity of a typical environmental ecology, making mangrove ecosystem have very complex functions from the physical, ecological, economic and socialcultural perspectives. Physical function serves as the facilitator of coastal edge, control of coastal erosion, maintaining sediment stability, extending the land area, and protecting coastal line [35]. The mangrove forest vegetation can grow in extreme areas for most of the 
plants, where mangrove can grow in areas with low oxygen content, high salinity (salt content), and influenced by sea tides [35]. From a social aspect, mangrove also serves to preserve the correlation of social relationship with local society, since coastal society needs mangrove to catch fish, crab, shrimp, wood, and ingredients for medicine [32]. This way, developing mangrove forests can be used as a preventive measure in disaster mitigation tsunami in the coastal society of Java.

\section{Conclusion}

The The Javanese people of folktales related to natural disaster mitigation include Timun Mas, Rawa Pening, and Nyi Roro Kidul. Timun Mas is related to the phenomena of the "mud volcano" disaster, Rawa Pening contains information of flood around Lake Rawa Pening, and Nyi Roro Kidul is related to the old catastrophe of tsunami occurring about 400 years ago. The three stories give knowledge of natural disaster mitigations that conform to the existing disasters. Timun Mas teaches humans to keep nature balanced; for example, if humans drill for oil and gas, they must make reclamation to repair the condition of the ecosystem around the drilling area. The story of Rawa Pening teaches humans not to pollute the water ecosystem around the lake, and of the vigilance of Javanese south coastal area of the tsunami by taking preventive measures of the making of mangrove forest, in which it is scientifically explained that a Mangrove Forest can minimize the power of waves hitting the coastal area.

The entire disaster mitigation measures from the folktales values are based on the fact that Javanese people often faced mud volcano (Lapindo), flood, and tsunami disasters especially in the south of Java-. In addition, the Indonesians should understand all of the advice contained in the folktales and that the folktales, which are all this time deemed myths, evidently also boast traditional knowledge on disaster mitigation. Applying the knowledge of disaster mitigation from the folktales is expected to give people early warning and contribute to mitigating the risks of natural disaster resulted.

This research is funded by The Directorate of Learning and Student Affairs, Directorate General of Higher Education, Ministry of Education and Culture on Students Scientific Competition (Social Humanity Research) in 2021.

\section{References}

1. P. A. Kaban, R. Kurniawan, R. E. Caraka, B. Pardamean, B. Yuniarto, Sukim, Biclustering Method to Capture the Spatial Pattern and to Identify the Causes of Social Vulnerability in Indonesia: A New Recommendation for Disaster Mitigation Policy, in Procedia Computer Science, 157, 31-37(2020)

2. E. Skoufias, E. Strobl, T. Tvei, Natural disaster damage indices based on remotely sensed data an application to Indonesia, World Bank Gr. Policy Res. Work. Pap., 81 (88), 1-34 (2017)

3. Z. Aidi, H. Farida, Natural disaster insurance for Indonesia disaster management, AES Bioflux, 12 (12), 137-145 (2020)

4. N. K. Agusintadewi, Membangun Budaya Tanggap Bencana Berbasis Kearifan Lokal di Indonesia, 117-122 (2020)

5. J. Danandjaja, Folklor dan Pembangunan Kalimantan Tengah: Merekonstruksi Nilai Budaya Orang Dayak Ngaju dan Ot Danum Melalui Cerita Rakyat Mereka, in Metodologi Kajian Tradisi Lisan, Keempat Ag., Yayasan Pustaka Obor Indonesia Jakarta, 79 (2015) 
6. S. Sukmawan, M. A. Nurmansyah, Etika Lingkungan Dalam Folklor Masyarakat Desa Tengger, Literasi, 2 (1), 88-95 (2012)

7. Erianjoni, Pengembangan Materi Ajar Sosiologi Tentang Mitigasi Bencana Berbasis Kearifan Lokal di Kota Padang, J. Sociol. Res. Educ., 4 (2), 96-107 (2017)

8. P. Lestari, Sularso, The COVID-19 Impact Crisis Communication Model Using Gending Jawa Local Wisdom, Int. J. Commun. Soc., 2 (1), 47-57 (2020)

9. M. Kristanto, Pemanfaatan Cerita Rakyat Sebagai Penanaman Etika Untuk Membentuk Pendidikan Karakter Bangsa, Mimb. Sekol. Dasar, 1 (1), 59-64 (2014)

10. N. Herlina, Metode Sejarah, in Journal of Chemical Information and Modeling, 2nd ed., Satya Historika Bandung, 53 (9), 1-30 (2020)

11. S. Sukmawan, Ekrokritik Sastra: Menanggap Sasmita Arcadia. Universitas Brawijaya Press (2016)

12. H. Amalia, Yulianeta, V. S. Damaianti, Pendekatan Geo-Cultural dan Geo-Mystisme dalam Legenda Rawa Pening sebagai Bahan Ajar Bahasa Indonesia Bagi Penutur Asing (BIPA), 67-72 (2008)

13. A. Findiyani, N. J. Utama, K. Anwar, Kearifan Lokal dan Mitigasi Bencana Masyarakat Pantai Selatan Kabupaten Cilacap, J. Indones. Hist., 19 (1), 28-37 (2020)

14. N. Setyowati, E. Emzir, N. Lustyantie, Nature and social attitude in folklore entitled Timun Mas: Eco-critical study, J. Appl. Stud. Lang., 4 (1), 38-47 (2020)

15. D. D. Nanda, B. Simbolon, F. A. Damanik, Y. B. Sembiring, Moral Value and Character Building Education in Folklore from Central Java 'Timun Mas, J. Lang. Lang. Teach., 9 (1), 85-91, 2021

16. S. Sukmawan, L. Setyowati, Environmental messages as found in Indonesian folklore and its relation to foreign language classroom, Arab World English J., 8 (1), 298-308 (2017)

17. B. D. Nurwicaksono, Folklor Lapindo Sebagai Wawasan Geo-Culture Dan GeoMythology Berbasis Kearifan Lokal Dalam Pembelajaran Bahasa Indonesia Bagi Penutur Asing (Bipa), J. Pendidik. Bhs. dan Sastra, 13 (1), 62-71 (2013)

18. J. Ekawati, G. Hardiman, E. Pandelaki, Analysis of GIS-Based Disaster Risk and Land Use Changes in The Impacted Area of Mudflow Disaster Lapindo, IOP Conf. Ser. Earth Environ. Sci., 409 (1), 1-12 (2020)

19. R. Endy, O. Syakir, Legenda Baru Klinting sebagai Ide dalam Berkarya Seni Ilustrasi dengan Teknik Papercut, J. Pendidik. Seni, 8 (2), 42-56 (2019)

20. C. Seftyono, Rawa Pening Dalam Perspektif Politik Lingkungan: Sebuah Kajian Awal, Indo. J. Conserv., 3 (1), 7-15 (2014)

21. U. Kulatunga, Impact of Culture towards Disaster Risk Reduction, Int. J. Strateg. Prop. Manag., 14 (4), pp. 304-313, 2010.

22. A. Santos, A. . Tavares, M. Queiros, Numerical modelling and evacuation strategies for tsunami awareness: lessons from the 2012 Haida Gwaii Tsunami, Geomatics, Nat. Hazards Risk, 7 (4), 1442-1449 (2016)

23. D. Muslim, E. Haerani, Z. Zakaria, R. I. Sophian, Disaster Culture For The School In Cisolok Of Sukabumi Regency, West Java, Indonesia, J. Pengabdi. Kpd. Masy., 4 (5), 70-79 (2018)

24. I. Setiawan, Mitos Nyi Roro Kidul dalam Kehidupan Masyarakat Cianjur Selatan, Patanjala, 1 (2), 188-200 (2009) 
25. A. Andayani, D. Jupriono, Representation of Nyi Roro Kidul in Myth, Legend, and Popular Culture, J. Lang. Lit. Cult. Stud., 2 (1), 28-36 (2019)

26. J. Becker, Gamelan Stories: Tantrism, Islam, and Aesthetics in Central Java, J. Asian Stud., 51 (1), 246-257 (1997)

27. E. Prawoto, L. Octavia, Disaster Storytelling: Extending the Memory ofthe Community Toward Disaster Preparednessfrom Myth, Scientific Explanation, and Popular Culture, J. Disaster Res., 16 (2), 228-233 (2021)

28. R. Retnowati, E. Ernawati, A. Akun, Ecocriticism Values In The Indonesian Folktale Timun Emas (Golden Cucumber), Humaniora, 9 (2), 221-229 (2018)

29. G. Subowo, Penambangan Sistem Terbuka Ramah Lingkungan Dan Upaya Reklamasi Pasca Tambang Untuk Memperbaiki Kualitas Sumberdaya Lahan Dan Hayati Tanah, J. Sumberd. Lahan, 5 (2), 83-94 (2011)

30. R. C. E. Permana, I. P. Nasution, J. Gunawijaya, Kearifan Lokal Tentang Mitigasi Bencana Pada Masyarakat Baduy, Makara, Sos. Hum., 15 (1), 67-76 (2011)

31. Tri Retnaningsih Soeprobowati, Mitigasi Danau Eutrofik: Studi Kasus Danau Rawa Pening, in Prosiding Seminar Nasional Limnologi VI, 36-48 (2012)

32. D. Santoro, M. Yamim, M. Mahrus, Penyuluhan Tentang Mitigasi Bencana Tsunami Berbasis Hutan Mangrove Di Desa Ketapang Raya Kecamatan Keruak Lombok Timur, J. Pengabdi. Magister Pendidik. IPA, 2 (1), 12-16 (2019)

33. R. Riyandari, The Role of Mangrove in The Protection of Coastal Area From Tsunami Waves, J. Sains dan Teknol. Mitication Bencana, 12 (1), 95-110 (2017)

34. K. Harada, H. Latief, F. Imamura, Effect on Reducing Tsunami by The Green Belt and Coastal Permeable Structure (2002)

35. S. Saputra, Sugianto, Djufri, Sebaran Mangrove Sebelum Tsunami dan Sesudah Tsunami di Kecamatan Kuta Raja Kota Banda Aceh, JESBIO, 5 (1), 35-47 (2016) 